\title{
Insulin Resistance as Predictor for Esophageal Varices in Hepatitis C Virus Cirrhosis
}

\author{
Fatma Mohamed Abd El-Salam ${ }^{1}$, Hatem Samir Abd El-Raouf ${ }^{1}$, \\ Salama Mohamed El Shinawy ${ }^{2}$ and Mohamed Shawky Mostafa ${ }^{3}$ \\ ${ }^{1}$ Hepatology, Gastroenterology and Infectious Diseases Department, Faculty of Medicine, \\ Benha University, Benha, Egypt. \\ ${ }^{2}$ Clinical pathology Department, Shebein EL-Kom Teaching hospital, Shebein EL-Kom, Egypt. \\ ${ }^{3}$ Hepatology, Gastroenterology and Infectious Diseases Department, Shebein El-Kom Teaching \\ Hospital, Shebein El-Kom,Egypt
}

Corresponding Author Mohammed Shawky Mostafa

Mobile:

$+201228135224$

E mail:

Dr.shawky2008@gmai l.com

Key words: Oesophageal varices, , Insulin resistance, Upper gastrointestinal endoscopy.
Background and study aim : Portal hypertension is one of the most important complications of liver cirrhosis. Endoscopic screening of all patients with liver cirrhosis would result in a large number of unnecessary additional burden to endoscopic units. This study is designed to assess insulin resistance in cirrhotic patients due to hepatitis C infection as non invasive parameter for esophageal varices.

Patients and Methods :This study was conducted on 50 cirrhotic patients (Child A) post hepatitis $\mathrm{C}$ who attended the Hepatology Department and outpatient clinic at Shebein El Kom Teaching Hospital. All the patients were evaluated by thorough history ,clinical examination, biochemical parameters ,metabolic features, including insulin resistance by

\section{INTRODUCTION}

Hepatitis $\mathrm{C}$ virus infection is a serious worldwide problem. It has been estimated that there are 130-150 million $\mathrm{HCV}$ infection worldwide, with 350 000 to 500000 people die each year from hepatitis C-related liver diseases [1].

Portal hypertension which is considered as one of the most important complications of liver cirrhosis is associated with development of a hyper dynamic circulation and complications such as ascites, hepatic encephalopathy and oesophago-gastric varices. Patients with cirrhosis and gastro-oesophageal varices have a hepatic venous pressure the homeostasis model assessment (HOMA), ultrasonongraphy, liver biopsy and upper gastrointestinal endoscopy to search for esophageal varices.

Results : EVs (esophageal varices) were detected in 18 of 50 patients. By multivariate analysis , the presence of EVs was independently associated with a low platelet count/spleen diameter ratio $(562.75 \pm 99.16)$, a high HOMA-IR score $(5.49 \pm 0.754)$, high body mass index , low hemoglobin, low albumin, high alanine aminotransferase and high aspartate aminotransferase.

Conclusion: Insulin resistance in patients with Hepatitis C virus cirrhosis (Child A ) measured by HOMA-IR score significantly predicts the presence esophageal varices in this patients and can be used as non-invasive parameter for predicting esophageal varices.

gradient during hemodynamic catheterization of at least $10-12 \mathrm{mmHg}$ [2].

Estimated prevalence of esophageal varices is approximately $50 \%$. The risk of bleeding from varices is $25 \%-35 \%$ with majority of the initial bleeding occurring within 1 year from varices detection [3].

Variceal bleeding is associated with a high morbidity and mortality The mortality associated with each episode of variceal bleeding ranges from $17 \%$ to $57 \%$ [4]. 
The incidence of bleeding can be reduced with nonselective beta-blockers [5].

It is also suggested that prophylactic endoscopic variceal band ligation can decrease the incidence of variceal bleeding and mortality in patients with liver cirrhosis who have large varices [6].

The prevalence of oesophageal varices among cirrhotic patients is variable, ranging from $24 \%$ to $80 \%$. Therefore, endoscopic screening of all patients with liver cirrhosis would result in a large number of unnecessary additional burden to endoscopic units [7].

Several studies have examined how to identify patients with varices using non-invasive or minimally invasive methods to avoid endoscopy in patients with a low risk of varices. These studies include biochemical, clinical and ultrasound parameters, transient elastography, CT scanning and video capsule endoscopy [8].

Insulin resistance (IR) is exceedingly common in patients with hepatitis $\mathrm{C}$ virus (HCV)-related chronic liver disease [9].

IR has been systematically associated with advanced fibrosis and fibrosis progression in several reports [10].

Camma and his colleagues identify a high HOMA-IR score as a new independent predictor of the presence of esophageal varices [11].

\section{PATIENTS AND METHODS}

Study design: Cross-sectional study.

\section{Patients}

We enrolled in the study 50 newly diagnosed patients with Child A HCV cirrhosis, consecutively observed at Hepatology department at Shebein El Kom Teaching Hospital in the period between May to December 2014, fulfilling all criteria detailed below.

\section{Inclusion criteria:}

Patients were included if they had a diagnosis of HCV cirrhosis based on liver biopsy.

\section{Exclusion criteria :}

(1) Advanced cirrhosis (Child-Pugh classes B and $\mathrm{C}$ ).

(2) Other causes of liver disease.

(3) Human immunodeficiency virus infection.
(4) Current or previous history of ascites or hepatic encephalopathy or portal hypertensive bleeding.

(5) Hepatocellular carcinoma.

(6) Portal vein thrombosis.

(7) Current treatment with any dosage of insulin.

(8) Previous or current treatment beta-blockers, diuretics, or other vasoactive drugs.

(9) Parenteral drug addiction or alcohol abuse in the last year.

(10) Type 2 diabetes.

The study was performed after written informed consent from all patients.

\section{Clinical and Laboratory Assessment}

The following data were collected at the time of recruitment: age, sex, weight, and height. Body mass index (BMI) was calculated as weight in kilograms/height in square meters. Patients with a BMI of 18.5 to $24.9 \mathrm{~kg} / \mathrm{m} 2$ were classified as normal, those with a BMI of 25 to 29.9 as overweight, those with a BMI of 30 or more as obese. Clinical examination for Signs of chronic liver disease.

A 12-hour overnight fasting blood sample was drawn at the time of recruitment to determine the serum levels of (AST-ALT-PT-INR-UreaCreatinine-CBC-Albumin-Bilirubin-HCV RNA and blood glucose level) Serum insulin was determined by enzyme-linked immunosorbent assay (Monobid Inc. Lake forest, USA).IR was determined by the homeostasis model assessment (HOMA) method by using the following equation: Insulin resistance (HOMA-IR=Fasting insulin $(\mu \mathrm{U} / \mathrm{mL}) \times$ fasting glucose $(\mathrm{mg} / \mathrm{dl}) / 405$ [12]. Cut off value for diagnosis of IR was $\geq 1.775$ according to the international diabetes federation (IDF) (left) and Adult Treatment Panel III (ATP III) in non-diabetic individuals.

\section{Instrumental Assessment}

After an overnight fast, all patients underwent an ultrasound examination with single viewer operator in supine position to detect the presence of liver cirrhosis (irregular surface, Irregular liver margins, coarse texture, attenuated hepatic veins, Relative enlargement of caudate lobe, signs of portal hypertension (presence of abdominal collaterals or splenomegally), ascites, portal vein diameter, splenic vein diameter, the span of the right lobe in the mid clavicular line on oblique view and classified as shrunken $(<11 \mathrm{~cm})$, average $(11-15 \mathrm{~cm})$ or enlarged $(>15 \mathrm{~cm})$ and to exclude hepatic focal lesion. 


\section{Upper gastrointestinal endoscopy}

Was done by the same endoscopist after fasting for at least 6 hours in left lateral position with examining esophagus for varices occurrence, size and risk signs of bleeding ( red wales\&cherry red spots and duodenum till second part and stomach for gastropathy and fundal varices.

Esophageal varices was graded on the basis of their size classification and according to AASLD guidelines as follows: Grade 1: Small straight cords of varices confined to the lower third of esophagus. Grade 2: Enlarged and tortuous varices occupying less than one third of the lumen. Grade 3: Large coil shaped esophageal varices occupying more than one third of the lumen $[\mathbf{1 3 , 1 4}]$.

\section{Statistical analysis}

Statistical presentation and analysis of the present study was conducted SPSS V.20. Data was expressed into two phases:

I- Descriptive 1- Mean value (X) and Standard Deviation [SD]: for quantitative data. 2Frequency and percenatage for qualitative data.

II- Analytic by t-student test and Chi-square test. $P$ value $>0.05$ was considered statistically non significant $\mathrm{P}$ value $\leq 0.05$ was considered statistically significant. $\mathrm{P}$ value $\leq 0.001$ was considered statistically highly significant. Variables found to be associated with the dependent variable at univariate logistic regression at a probability threshold of less than 0.10 were entered into multivariate logistic regression models. To avoid the effect of co linearity, HOMA-IR score, blood glucose levels and insulin levels as well as platelet count, spleen diameter, and platelet count/spleen diameter ratio, were not included in the same multivariate model.

\section{RESULTS}

Study was conducted on 50 patients,30(60\%) were males and 20(40\%) were females. Mean age was $42.32 \pm 10.13$, mean BMI was $33.8 \pm$ 2.73 and mean HOMA-IR was $31.43 \pm 3.23$. Baseline features of studied cases are present in table (1).

In the present study varices was present in 18 $(36 \%)$ of cases divided 11 patients was grade I and 7 patients was grade II. Factors associated with esophageal varices are shown in table (2).

In the present study high HOMA score and low platelets/splenic ratio were associated with varices presence. HOMA Cut off value was $\geq 3.6$, specificity $74 \%$, sensitivity $67 \%$, positive predictive value 77 and negative predictive value 63 .

ROC curves analysis (Fig. 1) identified HOMAIR score of $\geq 3.6$ (AUC, 0.621; SE, 0.061; 95\% CI, sensitivity, $67 \%$; specificity, $74 \%$; positive likelihood ratio, 2.82; negative likelihood ratio, $0.60)$ as the best cutoff for predicting the presence of EVs.

Figure (1): ROC curve for evaluating role of HOMA in prediction of varices

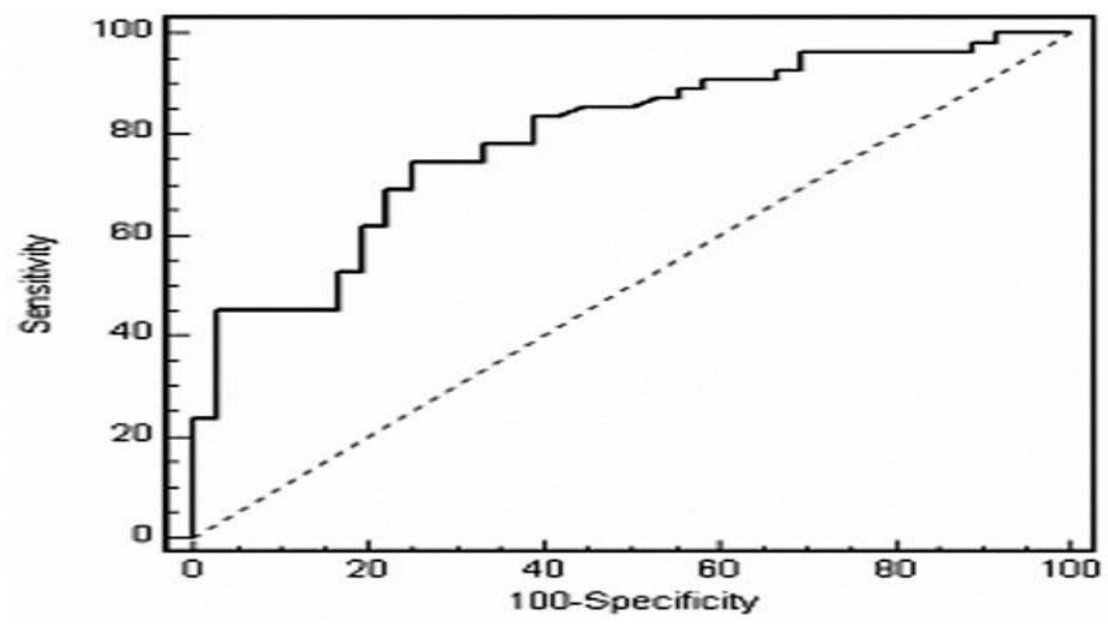


Table (1): Baseline features of studied cases $(n=50)$

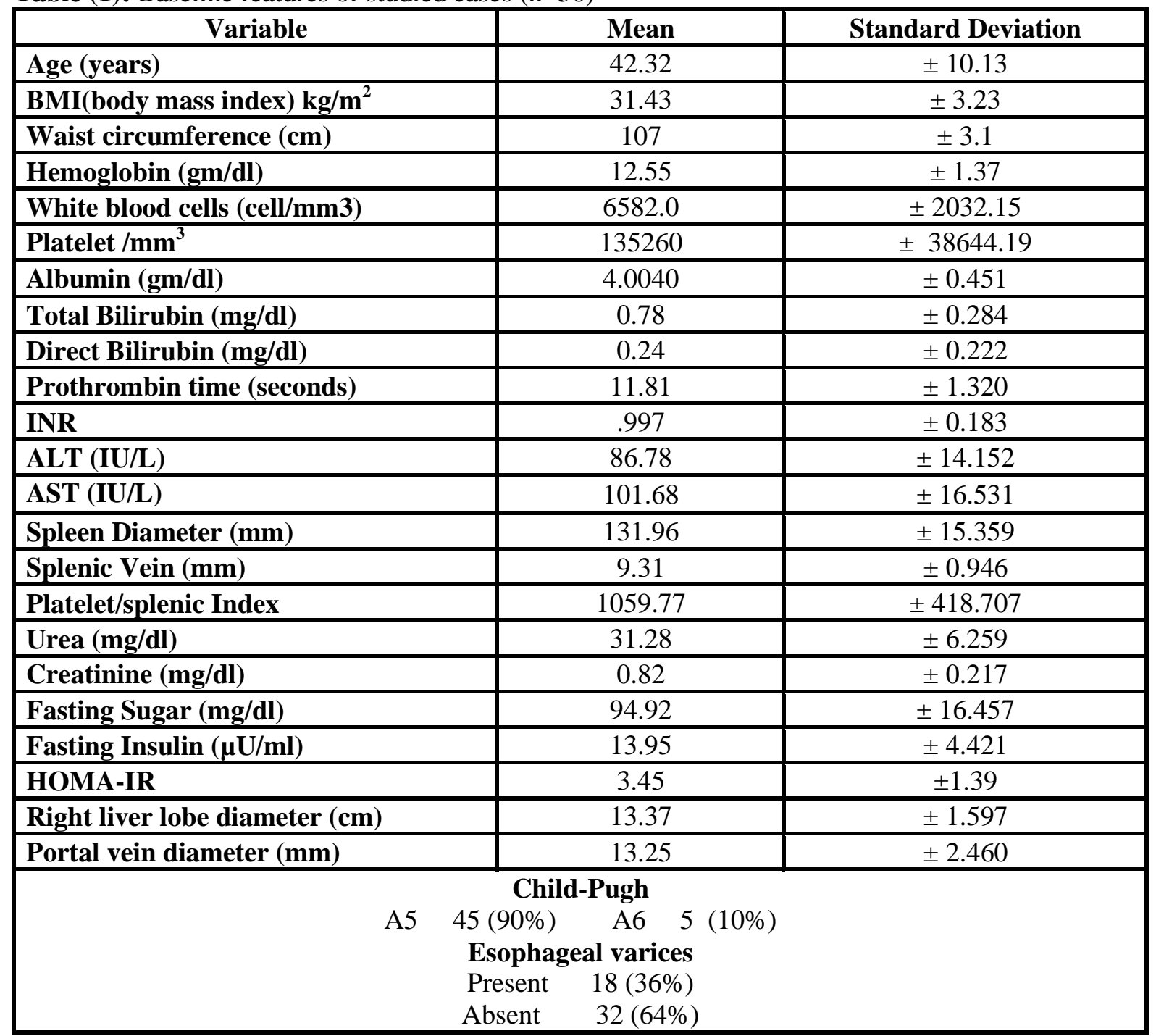


Table (2): Correlation between Data of the study and esophageal varices by univariate and multivariate analysis

\begin{tabular}{|c|c|c|c|c|}
\hline Variable & With varices $n=18$ & $\begin{array}{c}\text { Without varices } \\
\qquad \mathbf{n}=\mathbf{3 2}\end{array}$ & $\begin{array}{c}\text { Univariate } \\
\text { Analysis } \\
P \text { Value }\end{array}$ & $\begin{array}{c}\text { Multivariate } \\
\text { Analysis } \\
\text { OR }(95 \% \text { CI }) \\
\text { P Value }\end{array}$ \\
\hline Age (years) & $41.0 \pm 9.35$ & $43.06 \pm 10.63$ & 0.496 & - \\
\hline $\begin{array}{l}\text { BMI (body } \\
\text { index) } \mathrm{kg} / \mathrm{m}^{2}\end{array}$ & $33.8 \pm 2.73$ & $30.11 \pm 2.72$ & 0.002 & $0.624(0.015)$ \\
\hline Hemoglobin (gm/dl) & $11.52 \pm 1.01$ & $13.14 \pm 1.21$ & 0.001 & $2.931(0.024)$ \\
\hline $\begin{array}{l}\text { White blood cells } \\
(\text { cell/mm3) }\end{array}$ & $5727.77 \pm 1772.94$ & $7062.5 \pm 2035.13$ & 0.024 & $1.003(0.987)$ \\
\hline $\begin{array}{l}\text { Platelet } \times 10^{3} \\
(\text { cell } / \mathbf{m m 3})\end{array}$ & $71.0 \pm 16.28$ & $164.94 \pm 23.1$ & 0.001 & - \\
\hline Albumin (gm/dl) & $3.59 \pm 0.255$ & $4.23 \pm 0.366$ & 0.001 & $1.405(0.012)$ \\
\hline $\begin{array}{ll}\text { Total } & \text { Bilirubin } \\
(\mathrm{mg} / \mathrm{dl}) & \end{array}$ & $0.989 \pm 0.291$ & $0.663 \pm 0.204$ & 0.001 & $0.005(0.061)$ \\
\hline $\begin{array}{ll}\text { Direct } & \text { Bilirubin } \\
(\mathrm{mg} / \mathrm{dl}) & \\
\end{array}$ & $0.407 \pm 0.201$ & $0.148 \pm 0.033$ & 0.001 & $0.015(0.066)$ \\
\hline $\begin{array}{l}\begin{array}{l}\text { Prothrombin time } \\
\text { (seconds) }\end{array} \\
\end{array}$ & $12.88 \pm 1.27$ & $11.20 \pm 0.906$ & 0.001 & $0.251(0.071)$ \\
\hline INR & $1.15 \pm 0.185$ & $0.909 \pm 0.112$ & 0.001 & $0.00(0.091)$ \\
\hline ALT (IU/L) & $98.77 \pm 10.07$ & $80.03 \pm 11.42$ & 0.001 & $0.855(0.001)$ \\
\hline AST (IU/L) & $117.33 \pm 11.63$ & $92.87 \pm 11.64$ & 0.001 & $0.817(0.001)$ \\
\hline $\begin{array}{ll}\begin{array}{l}\text { Spleen } \\
(\mathrm{mm})\end{array} & \text { Diameter } \\
\end{array}$ & $147.22 \pm 14.84$ & $123.37 \pm 6.39$ & 0.001 & - \\
\hline Splenic Vein (mm) & $10.25 \pm 0.289$ & $8.78 \pm 0.755$ & 0.001 & $0.00(0.989)$ \\
\hline $\begin{array}{l}\text { Platelets/splenic } \\
\text { Index }\end{array}$ & $562.75 \pm 99.16$ & $1339.35 \pm 218.17$ & 0.001 & $0.855(0.001)$ \\
\hline Urea (mg/dl) & $29.83 \pm 6.62$ & $32.09 \pm 6.0$ & 0.224 & - \\
\hline Creatinine (mg/dl) & $0.783 \pm 0.217$ & $0.853 \pm 0.217$ & 0.281 & - \\
\hline Fasting Sugar (mg/dl) & $114.61 \pm 8.49$ & $83.84 \pm 6.06$ & 0.001 & - \\
\hline $\begin{array}{l}\text { Fasting Insulin } \\
(\mu \mathrm{U} / \mathrm{ml})\end{array}$ & $19.33 \pm 1.51$ & $10.93 \pm 1.85$ & 0.001 & - \\
\hline HOMA-IR & $5.49 \pm 0.754$ & $2.29 \pm 0.518$ & 0.001 & $1.0(0.020)$ \\
\hline $\begin{array}{lcc}\begin{array}{l}\text { Right liver } \\
\text { diameter }(\mathrm{cm})\end{array} & \text { lobe } \\
\end{array}$ & $11.36 \pm 0.564$ & $14.51 \pm 0.412$ & 0.001 & $0.00(0.996)$ \\
\hline $\begin{array}{l}\text { Portal vein diameter } \\
\text { (mm) }\end{array}$ & $16.25 \pm 1.14$ & $11.56 \pm 0.830$ & 0.001 & $0.00(0.995)$ \\
\hline
\end{tabular}




\section{DISCUSSION}

Portal hypertension is one of the main consequences of cirrhosis. It can result in severe complications, including bleeding of esophagogastric varices as well as spontaneous bacterial peritonitis or hepatorenal syndrome(HRS) as complications of ascites [15].

American Association for the Study of Liver Diseases 2007 single-topic symposium on portal hypertension [2] have recommended endoscopic screening for EV in patients with cirrhosis, regardless of Child class and cause. This policy is expensive, and it would be useful to have noninvasive predictors of $\mathrm{EV}$ in compensated Child A patients, at low risk of portal hypertension, as a pre-endoscopy screening tool. This goal was reasonably attained in the current study.

Several studies in chronic liver diseases have shown a strong and independent pathogenic link between IR (insulin resistance) and $\mathrm{HCV}$ infection $[\mathbf{1 0 , 1 6}]$ and between IR and the severity of hepatic fibrosis [9.10.16]. Although our work was not designed to clarify the pathogenic interaction between IR and presence of EVs, a few hypotheses can be put forward. Insulin is able to modulate the endothelial synthesis of nitric oxide and endothelin $[\mathbf{1 7 , 1 8}]$, to induce the production of tumor necrosis factor alpha and connective growth factor, and to stimulate hepatic stellate cells, $[19,20]$ the effectors in the pathogenesis of liver fibrosis and $\mathrm{PH}$ [21]. Therefore, insulin could contribute to the pathogenesis of $\mathrm{PH}$ by interfering with both mechanical and dynamic mechanisms leading to collagen deposition, vasoconstriction, and regulation of sinusoidal structure.

The study was conducted on 50 cirrhotic patients (Child A) post hepatitis $\mathrm{C}$ who attended the Hepatology department and outpatient clinic at Shebein El Kom Teaching Hospital.

In this study we aimed to identify HOMA-IR score, an easy biochemical marker, predicting the presence of EVs.

Several studies have shown that splenomegally [22,23], Child score [24], low serum HB level [24], low platelets $[\mathbf{2 5 , 2 6}]$, low albumin $[\mathbf{2 7 , 2 8}]$ ,liver enzymes [29], prothrombin time [24,28], high portal vein diameter [28], high splenic vein diameter [30], right liver lobe diameter [31] and Platelets count/spleen diameter ratio [11,32-35] could serve as predictors of EVs presence. However, all of these studies were quite heterogeneous, enrolling patients with cirrhosis of different causes (viral, alcoholic, and mixed) and different disease severity (Child B or end stage liver disease).

In our study HOMA-IR score for measuring insulin resistance was found higher in patients with varices (mean $=5.49 \pm 0.754)$ than patients without varices (mean $=2.29 \pm 0.518)$ as patients with varices were obese with central type. Statistically there was significance between high HOMA-IR score and esophageal varices presence $(\mathrm{p}=0.001)$.Cut off value was $\geq 3.6$,specificity $74 \%$, sensitivity $67 \%$,positive predictive value 77 and negative predictive value 63.As reported by Camm 'a and his collogues [11] that there was relation between HOMA-IR score and esophageal varices with cut off value $>3.5$, specificity $76 \%$, sensitivity $61 \%$.

The small number of patients included in our study and differences among studies in terms of demographic features, baseline severity, and cause of disease may explain the conflicting results, as well as differences in the statistical methods.

On performing multivariate logistic regression analysis, it was found that high body mass index, low hemoglobin level, low albumin level, high ALT, high AST, low PLT/Splenic ratio and high HOMA-IR score are significant predictors of esophageal varices presence.

The study has limitations. First, the analysis was carried out in a small number of patients, and it will be interesting to determine whether this association holds true also in larger groups of patients with HCV cirrhosis and in patients with liver disease of other origins. Lack of data on other variables, such as direct measurement of portal hypertension by HVPG, also could affect the interpretation of our findings. Finally, we cannot exclude the possibility that hidden abuse of alcohol may be responsible for the presence of $\mathrm{EV}$ in a few subjects.

In conclusion, insulin resistance in patients with Hepatitis $\mathrm{C}$ virus cirrhosis (Child A) measured by HOMA-IR score significantly predicts the presence esophageal varices in this patients and can be used as non-invasive parameter for predicting esophageal varices, and it is cheaper than endoscopy but not sufficient to be good negative test or surrogate marker alone, still endoscopy is the gold standard for diagnosis of varices. 


\section{ACKNOWLEDGEMENT}

The authors would thank Dr. Muhammed El Shewi and Dr. Sabry Abbas who helped in conducting this study.

Funding: None.

Conflicts of interest: The authors declare that there is no conflict of interest.

Ethical approval: Was granted by the Institutional Review Board and informed consent was obtained from each patient prior to inclusion in the study.

\section{REFERENCES}

1. World Health Organization . Hepatitis C: Key facts. WHO media center 2014.; No164.

2. Garcia-Tsao G, Sanyal AJ, Grace ND, Carey W, and the Pratice Guidelines Committee of the American Association for the Study of Liver Diseases .The Practice Parameters Committee of the American College of Gastroenterology. Prevention and management of gastroesophageal varices and variceal hemorrhage in cirrhosis. Hepatology 2007;46:922-938.

3. Jensen DM. Endoscopic screening for varices in cirrhosis: findings,implications, and outcomes. Gastroenterology 2002; 122:1620-30.

4. Garcia-Tsao G, Bosch J, Groszmann R . Portal hypertension and variceal bleeding unresolved issues. Summary of an American association for the study of liver diseases and European association for the study of the liver. Single-topic conference. Hepatology 2008; 47:1764-72.

5. Tripathi D, Hayes PC . Review article: a drug therapy for the prevention of variceal haemorrhage. Aliment Pharmacol Ther 2001; 15: 291-310.

6. Khuroo MS, Farahat KL, Sofi AA . Meta-analysis: endoscopic variceal ligation for primary prophylaxis of oesophageal variceal bleeding. Aliment Pharmacol Ther 2005; 21: 347-361.

7. de Franchis R . Portal Hypertension. Proceedings of the IVth Baveno International Consensus Workshop on Methodology of Diagnosis and Treatment in Portal Hypertension. Blackwell Science, Oxford, UK 2005; 154-158.

8. de Franchis R . Non-invasive (and minimally invasive) diagnosis of oesophageal varices. $J$ Hepatol 2008; 49:520-7.

9. Petta S, Camma' C, Di Marco V, Alessi N, Barbaria F, Cabibi D, et al. Retinol-binding protein 4: A new marker of virus-induced steatosis in patients infected with $\mathrm{HCV}$ genotype 1. Hepatology 2008sub epub..
10. Moucari R, Asselah T, Cazals-Hatem D, Voitot H, Boyer N. Insulin resistance in chronic hepatitis $\mathrm{C}$ : association with genotypes 1 and 4, serum $\mathrm{HCV}$ RNA level, and liver fibrosis. Gastroenterology 2008; 134:416-423.

11. Camm`a C, Petta S, Marco VD, Bronte F, Ciminnisi $\mathrm{S}$, Licata $\mathrm{G}$, et al. Insulin Resistance Is a Risk Factor for Esophageal Varices in Hepatitis C Virus Cirrhosis. Hepatology 2009; 49(1):195-203.

12. Matthews DR, Hosker JP, Rudenski AS, Naylor BA, Treacher DF, Turner RC. Homeostasis model assessment: insulin resistance and beta-cell functio from fasting plasma glucose and insulin concentrations in man. Diabetologia 1985; 28:412-419

13.Garcia-Tsao G, Sanyal AJ, Grace N . Prevention and management of esophageal varices and variceal bleeding in cirrhosis. Hepatology 2007; 46(3): 922-38.

14. Dite P, Labrecque D, Fried M. World Gastroenterology Organisation Practice Guideline: Esophageal varices.2008; JUN-1-8.

15. Nina Dib, Frédéric Oberti and Paul Calès . Current management of the complications of portal hypertension: variceal bleeding and ascites. CMAJ 2006; 174: 1433-43.

16. Hui JM, Sud A, Farrell GC, Bandara P, Byth K, Kench JG, et al. Insulin resistance is associated with chronic hepatitis $\mathrm{C}$ virus infection and fibrosis progression. Gastroenterology2003; 125:1695-1704.

17. Vincent MA, Montagnani M, Quon MJ . Molecular and physiologic actions of insulin related to production of nitric oxide in vascular endothelium. Curr Diab Rep 2003; 3:279-288.

18. Iwakiri Y, Groszmann RJ . Vascular endothelial dysfunction in cirrhosis. J Hepatol 2007; 46:927934.

19. Svegliati-Baroni G, Ridolfi F, Di Sario A, Casini A, Marucci L, Gaggiotti G, et al. Insulin and insulinlike growth factor-1 stimulate proliferation and type I collagen accumulation by human hepatic stellate cells: differential effects on signal trans-duction pathways. Hepatology 1999; 29:1743-1751.

20. Paradis V, Perlemuter G, Bonvoust F, Dargere D, Parfait B, Vidaud M, et al. High glucose and hyperinsulinemia stimulate connective tissue growth factor expression: a potential mechanism involved in progression to fibrosis in nonalcoholic steatohepatitis. Hepatology 2001; 34:738-744.

21. Rockey DC. Hepatic fibrosis, stellate cells, and portal hypertension. Clin Liver Dis 2006; 10:459479 
22 Lopamudra M, Sanjay M, Dipanjan B, Puneet Kumar MJ Jacob AG, Puneet Kumar, et al. Correlation of portal vein diameter and splenic size with gastro-oesophageal varices in cirrhosis of liver. JIACM 2011; 12(4): 266-70.

23 Chang MH, Sohn JH, Kim TY, Son, BK, Kim, J.P, Jeon YC, et al. Non-endoscopic predictors of large esophageal varices in patients with liver cirrhosis. Korean J. Gastroenterology 2007; 49 (6): 376-83.

24. Madhotra R, Mulcahy H, Willner I, Reuben A. Prediction of esophageal varices in patients with cirrhosis. J. Clin. Gastroenterology 2002; 34: 4-5.

25. Esmat S, Omarn D, Rashid L . Can we consider the right hepatic lobe size/albumin ratio a noninvasive predictor of oesophageal varices in hepatitis $\mathrm{C}$ virus-related liver cirrhotic Egyptian patients?. European Journal of Internal Medicine 2012; 23:267-272.

26. Agha A, Anwar E, Bashir K, Savarino V,Giannini EG . External validation of the platelet count/spleen diameter ratio for the diagnosis of esophageal varices in hepatitis $\mathrm{C}$ virus-related cirrhosis. Dig Dis Sci 2009; 5 4(3):654-60.

27. Sarwar S, Khan AA, Butt AK, Shafqat F, Malik K, Niazi AK, et al. Non-endoscopic prediction of presence of esophageal varices in cirrhosis.JColl Physicians Surg Pak 2005; 15:528-531.

28. Schepis F, Camma C, Niceforo D, Magnano A, Pallio S, Cinquegrani M, et al. Which patients with cirrhosis should undergo endoscopic screening for esophageal varices detection? Hepatology 2001 ; 33: 333-338.

29. Vanbiervliet G, Barjoan-Marine E, Anty R, Piche T, Hastier P, Rakotoarisoa C, et al. Serum fibrosis markers can detect large esophageal varices with a high accuracy. European J. of Gastroenterology. Hepatology 2005; 17 (3): 333-338.
30. Kazemi F, Kettaneh A, N'kontchou G, Pinto E, Ganne-Carrie N, Trinchet, J.C, et al. Liver stiffness measurement selects patients with cirrhosis at risk of bearing large oesophageal varices. J Hepatology 2006; 45:230-235.

31. Tamara Alempijevic, Vladislava Bulat, Srdjan Djuranovic, Nada Kovacevic, Rada Jesic, Benhamou JP, et al. Right liver lobe/albumin ratio: Contribution to non-invasive assessment of portal hypertension. World J Gastroenterol 2007; 13(40): 5331-5.

32. Gainnini E, Botta F and Borro P, Risso D, Romagnoli P .Platelet count/spleen diameter ratio: proposal and validation of a non-invasive parameter to predict the presence of oesophageal varices in patients with liver cirrhosis. Gut 2003; 52 (8): 1200-1205.

33. Sether GH, Ahmed R, Rathi SK, Shaikh NA Platelet count/splenic size ratio: a parameter to predict the presence of esophageal varices in cirrhosis. $J$ Coll. Physicians Surg Pack 2006; 16 (3): 183-6.

34. Zapater P. Franc R, Such J . Insulin Resistance and Platelet Count/Spleen Diameter Ratio: Two Simple, Easy-to-Get Tests for Predicting Esophageal Varices in Cirrhosis. Hepatology 2009; 1394.

35. Li X, Wu K, Fan D . Insulin resistance and platelet count/spleen diameter ratio: two simple, easy-to-get tests for predicting the esophageal varices in cirrhosis. Hepatology 2009; 49:1374.

Peer reviewers: Dr. Ahmed El-deep, Department of Internal Medicine, Faculty of Medicine, Mansoura University, Egypt; Dr. Basem Attia, Internal Medicine Department, Faculty of Medicine, Zagazig University, Egypt.

Editor: Mohamed H Emara; Lecturer of Tropical Medicine, Faculty of Medicine, Zagazig University, Egypt. 